\title{
The age and origin of the Gelderse IJssel
}

\section{B. Makaske ${ }^{1, *}$, G.J. Maas $^{1}$ \& D.G. van Smeerdijk ${ }^{2}$}

1 Alterra, Wageningen University and Research Centre, P.0. Box 47, 6700 AA Wageningen, the Netherlands.

2 BIAX Consult, Hogendijk 134, 1506 AL Zaandam, the Netherlands.

* Corresponding author. Email: bart.makaske@wur.nl

Manuscript received: February 2008; accepted: September 2008

\begin{abstract}
The Gelderse IJssel is the third major distributary of the Rhine in the Netherlands and diverts on average 15\% of the Rhine discharge northward. Historic trading cities are located on the Gelderse IJssel and flourished in the late Middle Ages. Little is known about this river in the early Middle Ages and before, and there is considerable debate on the age and origin of the Gelderse IJssel as a Rhine distributary. A small river draining the surrounding Pleistocene uplands must have been present in the IJssel valley during most of the Holocene, but very diverse opinions exist as to when this local river became connected to the Rhine system (and thereby to a vast hinterland), and whether this was human induced or a natural process. We collected new AMS radiocarbon evidence on the timing of beginning overbank sedimentation along the lower reach of the Gelderse IJssel. Our data indicate onset of overbank sedimentation at about $950 \mathrm{AD}$ in this reach. We attribute this environmental change to the establishment of a connection between the precursor of the IJssel and the Rhine system by avulsion. Analysis of previous conventional radiocarbon dates from the upper IJssel floodplain yields that this avulsion may have started $\sim 600 \mathrm{AD}$. Our results contradict earlier suppositions, based on interpretation of archaeological data and historical accounts, that the Gelderse IJssel is much older and originated as a canal, dug under supervision of the Roman general Drusus.
\end{abstract}

Keywords: avulsion, Drusus, Gelderse IJssel, overbank deposits, Rhine, radiocarbon age determination.

\section{Introduction}

The Gelderse IJssel is a major Rhine distributary (Fig. 1) that ranks third in size after the Waal and the Nederrijn-Lek, and on average discharges about $300 \mathrm{~m}^{3} / \mathrm{s}$. Especially in the late Middle Ages, the Gelderse IJssel (henceforth called IJssel) was important as a shipping route playing an important role in the rise of Hansa cities like Kampen, Deventer, Zutphen and Doesburg (Fig. 1). At that time, the IJssel was still a natural, freely meandering river. In the course of the 16th century $A D$ the IJssel started silting up, which ultimately led to engineering works upstream in the beginning of the 18th century AD to improve water supply and navigation depth. At present, the IJssel channel is trained with groynes and bank reinforcements, and a system of waterworks cause diversion of a fixed portion ( 15\%) of the total Rhine discharge into the IJssel.
While the history of the IJssel during and after the late Middle Ages is well known, the importance and development of the river in the early Middle Ages is still obscure. Especially the age and origin of the IJssel as a Rhine distributary has been a subject of much discussion among historians, archaeologists, geographers and geologists for more than a century. Because of the scarcity of historical sources from this earlier period, many of the arguments put forward in the discussion rely on interpretations of archaeological finds and geological data.

Geologically, the IJssel channel is scoured into the LatePleistocene and Holocene fill of a valley of (largely) Saalian glacial origin (Busschers et al., 2007). The Holocene floodplain is bordered by Pleistocene uplands (Fig. 1), comprising river terraces, aeolian (coversand) dunes and plains, and glacial icepushed ridges with associated periglacial landforms. During 


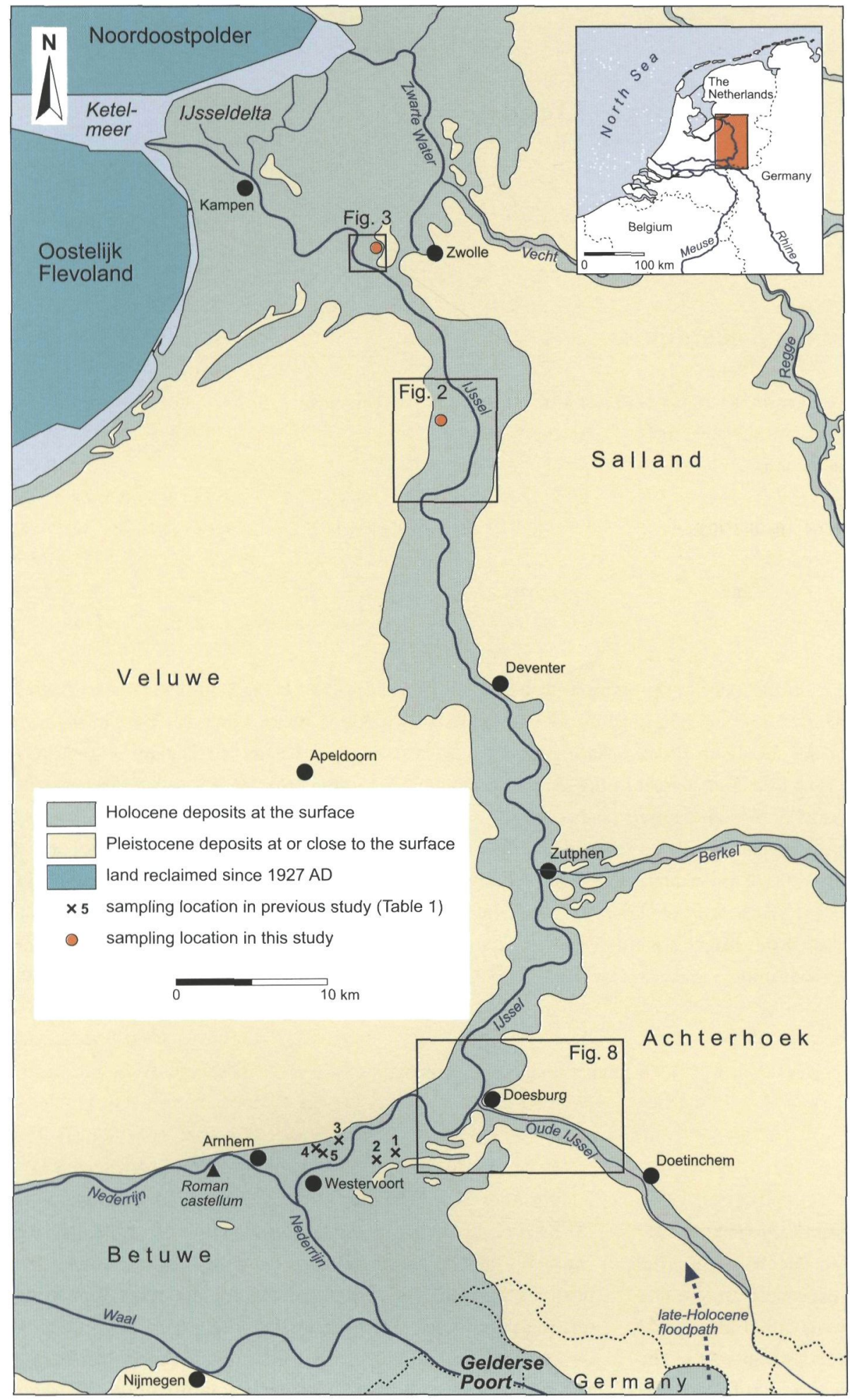

Fig. 1. Map of the IJssel valley showing localities mentioned in the text, sampling locations, the locations of Figs 2, 3 and 8, and the location of the Roman castellum referred to in the text. Distinction between Holocene and Pleistocene deposits based on the Geomorphological Map of the Netherlands (Koomen \& Maas, 2004). most of the Holocene, a small river must have existed in the IJssel valley, fed by the Berkel and a few minor streams draining the surrounding Pleistocene uplands. The question is when and how a connection between the Nederrijn (or a precursor Rhine branch) and this small river in the IJssel valley came into existence.
The objectives of this paper are: 1) to evaluate the existing data on the age and origin of the IJssel, 2) to present new evidence on the age of the IJssel, and 3) to discuss this new evidence in relation to previous work and geomorphological observations. 


\section{Previous research}

\section{Weichselian and early-Holocene palaeogeographical developments}

During the Early Weichselian, the Rhine flowed northward through the IJssel valley, entering it from the southeast, roughly following the valley of the present Oude IJssel southeast of Doetinchem (Van de Meene, 1979; Fig. 1). In the Middle Weichselian (Middle Pleniglacial) the Rhine changed its course westward, to the present Rhine-Meuse delta, near Doesburg and abandoned its course through the lower IJssel valley (Busschers et al., 2007). In the Late Weichselian, the Rhine gradually abandoned its course through the Oude IJssel valley. At that time, the Rhine entered the Netherlands through its present more southerly course (in the Gelderse Poort area; Fig. 1) (Busschers et al., 2007). Climatically induced stepwise incision and associated terrace formation (e.g. Berendsen et al., 1995) continued in the lower Rhine and Meuse valleys in the Late-Weichselian and Early-Holocene periods, ultimately leading to relatively narrow incised channel belts with surface levels below wide abandoned Weichselian terraces (Cohen, 2003; Gouw \& Erkens, 2007) .

Following abandonment by the Rhine, a local drainage system had established in the IJssel valley north of Doesburg. A low divide, consisting of abandoned Middle-Weichselian Rhine terraces, existed across the IJssel valley near Doesburg. We suppose (see section 'The IJssel avulsion') that this divide remained intact during most of the Holocene, with the Oude IJssel flowing from Doesburg to the southwest and joining the Rhine near Arnhem, thereby following the overall gradient of the shallow Late-Weichselian subsurface.

Primarily under influence of rapid relative sea-level rise, aggradation of the incised Rhine and Meuse channel belts occurred in the Middle Holocene, starting in the west and gradually occurring more and more upstream. Approximately 4000 BP the upstream limit of onlap of Holocene deposits on Weichselian terraces had reached the area near Arnhem and Westervoort (Gouw \& Erkens, 2007) (Fig. 1). Herewith, one condition promoting a northward avulsion of the Rhine into the IJssel valley was satisfied: especially aggrading rivers with lateral floodplains are prone to avulsion. Another favourable condition is an energetic (usually gradient) advantage of the avulsion route over the existing channel. Because the Westervoort-Doesburg reach of the IJssel valley dipped southwestward (the direction of Late-Weichselian Rhine flow in this part of the IJssel valley), substantial additional aggradation in the area Arnhem-Westervoort was needed to reverse the direction of slope and create a northward gradient advantage, facilitating avulsion.

\section{Radiocarbon age determinations}

Numerous radiocarbon dates relating to the age of Rhine distributaries are available from the Rhine-Meuse delta (summarized by Berendsen \& Stouthamer, 2001). In general, the age of beginning overbank sedimentation is taken to represent the age of formation of the stratigraphically associated channel belt. For dating the beginning of overbank sedimentation, radiocarbon age determination is carried out of the top of a peat bed that is non-erosively overlain by overbank deposits (e.g. Berendsen, 1982, pp. 114-118). From five locations on the upper reach of the IJssel (Fig. 1) radiocarbon age determinations from the top of a peat bed underlying overbank deposits are available (Table 1).

An often cited radiocarbon age determination suggesting a Roman age of the IJssel is GrN-5491: $2000 \pm 65{ }^{14} \mathrm{C}$ yr BP (Vogel \& Waterbolk, 1972; Lanting \& Mook, 1977; Teunissen, 1980). The dated peat sample was collected in 1967 by J.N.B. Poelman in the Giesbeekse Broek area (location 1 in Fig. 1) near a borehole cross-section that was published by Poelman \& Harbers (1966). This cross-section reveals a strongly decomposed, dark top of the dated peat bed. This dark top horizon is discontinuous and of variable thickness (up to at least $30 \mathrm{~cm}$ (Poelman 1981b, p. 174)). The boundary between the sampled dark peat and the overlying clay is sharp (Poelman 1981b, p. 174). These phenomena suggest that: 1 ) the top of the peat has been eroded, at least in parts of the cross-section; 2) there has been a time gap between the end of peat-growth and the beginning of fluvial clay deposition during which the observed soil formation in the peat could take place. Thus, the top of the peat may be older than the beginning of overbank deposition from the IJssel. Teunissen $(1981,1990)$ disputed the existence of a significant time gap based on his palynological analyses and proposed that rapid peat decomposition could have resulted from the change to eutrophic circumstances with first clay deposition. Additional age determinations (carried out later) of material from various depths at the same location (Table 1) show stratigraphic inconsistency: GrN-5491 is obviously too old to fit into the series and should therefore be rejected.

From the Lathumse Broek (location 2 in Fig. 1), a younger date from the top of the peat bed was obtained: $1720 \pm 25{ }^{14} \mathrm{C}$ yr BP (GrN-7525). According to Poelman (1981b, p. 174), the top of the (slightly clayey) peat bed was dark and decomposed and sharply overlain by overbank clay. Teunissen (1990, p. 100), however, stated that his pollen diagram and organic matter analyses indicate a gradual peat-clay transition, without a depositional hiatus. Because of the stratigraphic consistency of the series of dates from this location (Table 1) GrN-7525 was accepted by Törnqvist (1993, p. 150) as representing the age of the IJssel. Following Törnqvist, Berendsen \& Stouthamer (2001, app. 1) also assumed start of IJssel activity at 1700 BP. The selection of GrN-7525 is quite arbitrary, however, because from three other locations on the upper IJssel floodplain younger dates of the upper peat bed exist (Table 1). 
At location 3 (Fig. 1) the top of the peat bed was dated at $1575 \pm 35{ }^{14} \mathrm{C}$ yr BP (GrN-10293). Because this peat was strongly decomposed, beginning IJssel overbank deposition could have been younger. Strong changes in organic matter content and pollen composition directly above the dated level (Teunissen, 1990, pp. 111-112) also suggest a time gap. Indeed, a somewhat younger date is available from location $4: 1420 \pm 30^{14} \mathrm{C}$ yr BP (GrN-12604). This is an unpublished date from Teunissen of a thin ( $<10 \mathrm{~cm}$ thick) peat bed on top of Pleistocene gravelly sand grading upward into humic clay (field observations first author). Strong decomposition of this shallow peat bed probably is due to recent drainage. An even younger date is available from location 5, which is closer to the IJssel: $1265 \pm$ $45{ }^{14} \mathrm{C}$ yr BP (GrN-14407). The latter date represents the clayey top of a 2.5-m-thick peat bed of which two deeper dates exist that are stratigraphically consistent (Table 1). One of these, GrN-14410, is believed to be a few centuries too old for palynological reasons (Teunissen, 1990, p. 109).

Given the present radiocarbon data set, the start of IJssel activity could be considerably younger than 1700 (Törnqvist, 1993; Berendsen \& Stouthamer, 2001) or 2000 BP (Teunissen, 1980). It should also be noted that all radiocarbon dates available are conventional dates of bulk peat samples. Such dates in general are less accurate than AMS dates of selected terrestrial macrofossils (Törnqvist et al., 1992).

\section{Stratigraphic analysis and indirect dating}

Widely variable ages of the IJssel have been proposed by various authors based on interpretation of stratigraphy and indirect dating. Hamming et al. (1965) studied IJssel deposits in an excavation near Zwolle and supposed onset of IJssel overbank deposition near Zwolle after Roman times (i.e., 250 AD), to some extent supported by palynological analysis. Ente (1971, 1973-1974) reconstructed the genesis of the IJssel delta using many deep boreholes and concluded that delta formation near Kampen started in the 12th century. This age estimate relied on stratigraphic correlation of an archaeological find (a sarcophagus cover) in the lacustrine deposits north of the delta with the early delta deposits. Partly based on historical reflections, however, he considered it likely that the upper IJssel (reach Westervoort-Doesburg) already existed in the 8th or 9 th century.

Van de Meene (1979) and Harbers \& Mulder (1981) investigated the soils and stratigraphy of the upper IJssel floodplain between Westervoort and Doesburg. They believed that the origin of the upper reach of the IJssel may date back to late Subboreal (Harbers \& Mulder, 1981) or early Subatlantic times (Van de Meene, 1979). With the Subboreal-Subatlantic transition at $900 \mathrm{BC}$, this is much earlier than suggested by radiocarbon dates from the same area discussed above. Harbers \& Mulder (1981) argued that the upper IJssel could initially have existed in this area as a small stream without depositing overbank sediments. In contrast, Van de Meene (1977) supposed late Subboreal initial overbank deposition marking increasing influence of the Rhine, with upper IJssel channel formation starting in Subatlantic times.

\section{The Drusus canal}

In classic Roman sources (Tacitus, annales II, 8; Suetonius, Claudius I, 2) mention is made of military strategic waterworks in the lower Rhine area, including a canal dug under supervision of the Roman general Drusus, leading (northward) into

Table 1. Radiocarbon age determinations from the upper IJssel floodplain. Italics indicate for each core the date closest to the top of the upper peat bed.

\begin{tabular}{|c|c|c|c|c|c|}
\hline Core (Fig. 1) & Laboratory number & ${ }^{14} \mathrm{C}$-age (yr BP) & Depth below surface $(\mathrm{cm})$ & Material & Reference \\
\hline 1 & GrN-11871 & $1590 \pm 60$ & $103.5-107$ & clay & Teunissen $(1988,1990)$ \\
\hline 1 & GrN-5491 & $2000 \pm 65$ & $106-108$ & peat $^{1}$ & Vogel \& Waterbolk (1972) \\
\hline 1 & GrN-11870 & $1820 \pm 50$ & $117-120$ & clayey peat & Teunissen $(1988,1990)$ \\
\hline 1 & GrN-11869 & $1910 \pm 60$ & $124.5-127.5$ & clayey peat & Teunissen $(1988,1990)$ \\
\hline 1 & GrN-11868 & $2810 \pm 70$ & $142-144.5$ & peat & Teunissen (1990) \\
\hline 2 & GrN-11126 & $1495 \pm 25$ & $95-97$ & humic clay & Teunissen $(1988,1990)$ \\
\hline 2 & GrN-7525 & $1720 \pm 25$ & $102-110$ & sl. clayey peat ${ }^{1}$ & Teunissen $(1980,1990)$ \\
\hline 2 & GrN-11894 & $1830 \pm 110$ & $110-115$ & sl. clayey peat & Teunissen $(1988,1990)$ \\
\hline 2 & GrN-11289 & $2230 \pm 80$ & $117-121$ & sl. clayey peat & Teunissen $(1988,1990)$ \\
\hline 2 & GrN-10129 & $2520 \pm 70$ & $140-144$ & clayey peat & Teunissen (1990) \\
\hline 3 & GrN-10293 & $1575 \pm 35$ & $140-144$ & peat ${ }^{2}$ & Teunissen $(1988,1990)$ \\
\hline 4 & GrN-12602 & $1420 \pm 30$ & $83-86$ & sandy peat ${ }^{2}$ & Teunissen (unpubl.) \\
\hline 5 & GrN-14407 & $1265 \pm 45$ & $162-165$ & clayey peat & Teunissen $(1988,1990)$ \\
\hline 5 & GrN-14410 & $1915 \pm 50$ & $201-203$ & peat & Teunissen $(1988,1990)$ \\
\hline 5 & GrN-14411 & $2140 \pm 50$ & $233-235$ & peat & Teunissen $(1988,1990)$ \\
\hline
\end{tabular}

Decomposed (Poelman, 1981b, p. 174).

Strongly decomposed. 
hostile territory. This canal was used for a military campaign in $12 \mathrm{BC}$. The exact position of the Drusus canal has been a subject of much debate among archaeologists and historians, with the upper IJssel floodplain between Westervoort and Doesburg being considered as a likely location by a large number of authors since the 16th century (see references in Teunissen, 1975, 1980). A canal in this area could have connected the Rhine with a drainage system in the middle and lower IJssel valley and as such have been the precursor of the present upper IJssel. In this view, the Oude IJssel is considered to have been a tributary of the IJssel valley drainage system in Roman times, instead of a Rhine tributary (see section 'The IJssel avulsion').

Data that seem to support this hypothesis are radiocarbon date GrN-5491 (2000 $\pm 65^{14} \mathrm{C}$ yr BP) and the remains of a Roman castellum near Arnhem (Fig. 1) discovered in 1979 (Teunissen, 1980; Willems, 1980, 1981, 1986). Willems (1980) argued that the existence of a canal would very well explain the location of this fortification. We feel that GrN-5491 cannot serve as an argument in favour of a Drusus canal between Westervoort and Doesburg, because this date is stratigraphically inconsistent and should therefore be rejected (see above). Poelman (1981a,b) disputed the conclusions of Teunissen (1980) and Willems $(1980,1981)$ for pedological and palynological reasons.

\section{Collection of new radiocarbon data}

\section{Selection of study areas}

The ambiguity of the radiocarbon ages obtained hitherto, and the strongly divergent views on the age and origin of the IJssel, were the motive for new field research. Erosion of the peat underlying the upper IJssel overbank deposits between Westervoort and Doesburg was considered a potential cause of the variability of the radiocarbon dates from this area, and therefore the focus of this new study was on the lower reaches of the IJssel from which no radiocarbon dates indicating the age of the IJssel were available.

Only at a few locations in the middle and lower IJssel valley substantial Holocene peat has developed. A soil map (Stiboka, 1966) and the Geomorphological Map of the Netherlands (Koomen \& Maas, 2004) suggest the floodbasin near Wapenveld (Fig. 2) as one of very few suitable locations. Approximately 5 $\mathrm{km}$ downstream of Wapenveld, the IJssel valley narrows with the glacial ice-pushed ridge on the west-side approaching the river. Downstream of this narrow, a suitable location (Eilander \& Heijink, 1990) is just northwest of Zwolle (Fig. 3), near the former village of Westenholte. This location is well upstream of the IJssel delta. Considerable floodplain width at these two locations allowed sampling the top of the peat beneath IJssel overbank deposits outside the natural levee zone (Figs 2 and 3 ) where erosion of underlying peat is more likely than farther away from the IJssel channel. In both areas borehole crosssections were constructed more or less perpendicular to the IJssel River to facilitate selection of optimum sampling locations.

\section{Wapenveld study area}

Cross-section Wapenveld 1 (Fig. 4) shows the fill of an abandoned IJssel channel in its central part, which consists of silty and sandy clay. The natural levee deposits of the present IJssel channel occur more to the east as a wedge of silty and sandy clay hosting the dyke that bounds the embanked section of the IJssel floodplain that occurs to the east. The floodbasin deposits of the IJssel appear as a wedge of clay, thinning away from the present IJssel channel, encasing the upper part of the channel-fill, and overlying a bed of peat and clayey peat. The clastic IJssel deposits belong to the Echteld Formation, whereas the peat belongs to the Nieuwkoop Formation (cf. Westerhoff et al., 2003).

The clastic deposits below the peat consist mainly of sand that may be gravelly. The sandy deposits are draped by a clay bed (locally sandy or silty) that thins to the west. The top of the sandy deposits shows a step of about $1 \mathrm{~m}$, which is taken to represent the boundary between two buried river terraces. The sandy deposits are interpreted to predominantly belong to the Kreftenheye Formation (Westerhoff et al., 2003), which occurs throughout the IJssel valley as the product of Weichselian braided rivers that were part of the Rhine system (Van de Meene, 1979; Verbraeck, 1990). However, because of the long exposure at the surface after abandonment by the Rhine, the original braidplain has been reworked by local rivers, and aeolian and periglacial processes (e.g. Busschers et al., 2007), of which the sedimentary products belong to the Boxtel Formation (Westerhoff et al., 2003) and are hard to distinguish in the field from the Kreftenheye deposits. We expect a local component (e.g. material derived from the glacial ice-pushed ridges) to be present in the basal sandy deposits of Cross-section Wapenveld 1 too. The capping clay on top of the sandy deposits is classified as Boxtel Formation and is taken to represent the overbank deposits of a meandering local river. Thickening of these deposits towards the east suggest that the former channel has been located near the present IJssel River that perhaps rejuvenated this old course. The local meandering river was probably mainly fed by the Berkel. East of Zutphen, the Berkel shows large palaeomeanders (Maas \& Makaske, in prep.) that may have been active until early-Holocene times (Bos et al., 2005).

The fill of the palaeochannel in the central part of the crosssection is fine-grained, contrasting with the coarse deposits into which the channel base has scoured. This suggests a relatively sudden abandonment, possibly following an avulsive shift of the IJssel channel to its present location. Channel-fill width is $\sim 110 \mathrm{~m}$, somewhat less than the historical width of 
Fig. 2. Geomorphological map of the Wapenveld study area (see Fig. 1 for location), with the locations of the borehole cross-sections Wapenveld 1 and Wapenveld 2. This map is an updated detail from the Geomorphological Map of the Netherlands (Koomen \& Maas, 2004). The legend only explains the most important map units that are marked with codes. It shows the large floodbasin east and southeast of Wapenveld. An abandoned channel (code 2R11) exists to the east between this floodbasin and the present IJssel channel belt. The provincial boundary between Gelderland (west) and Overijssel (east) partly follows this abandoned channel. To the west, the floodplain is bounded by glacial and periglacial landforms, locally covered by coversand ridges and (more recent) inland dune complexes.

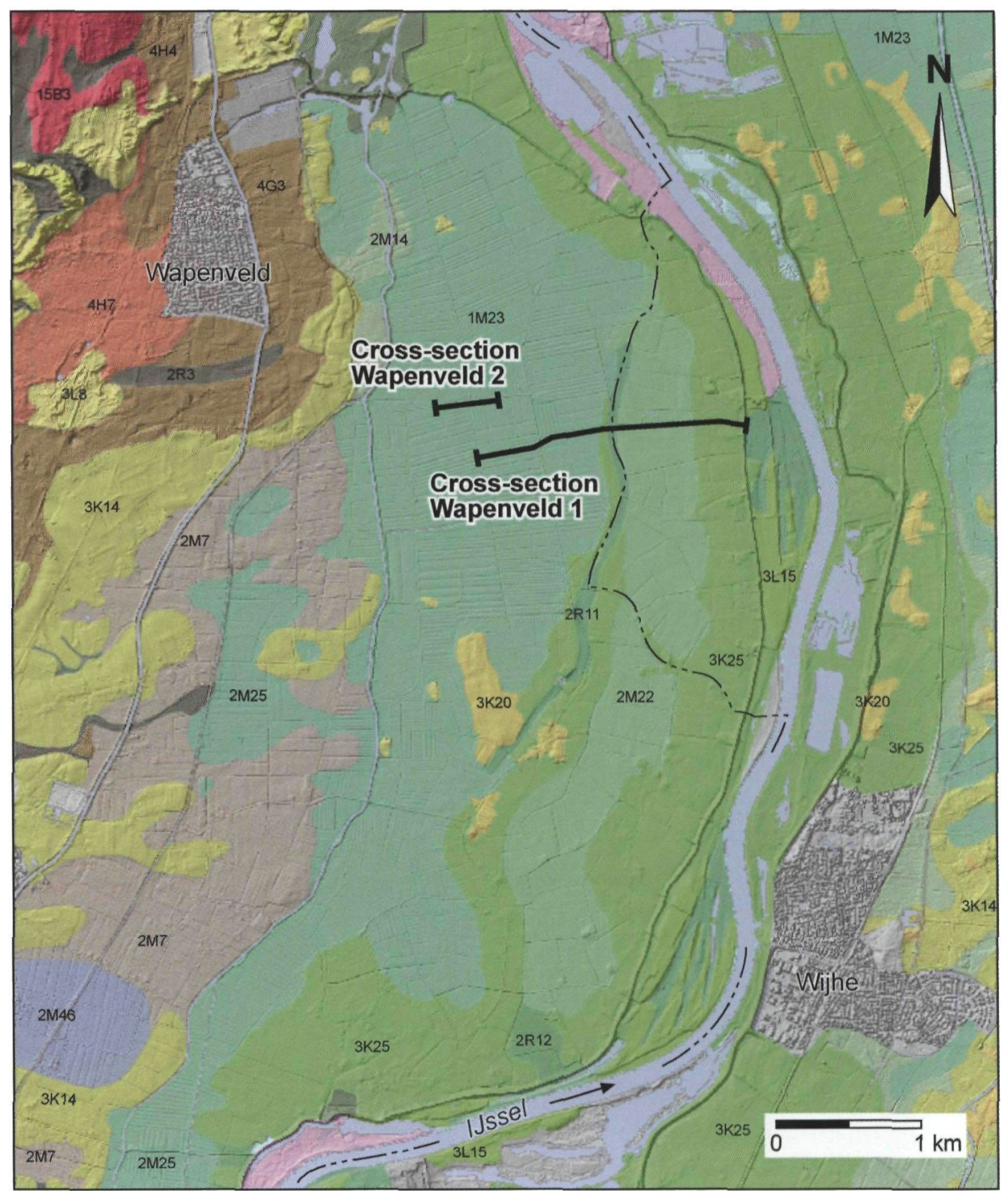

\section{Fluvial landforms}

\begin{tabular}{|l|l}
\hline $2 \mathrm{M} 25$ & river floodplain \\
\hline $1 \mathrm{M} 23$ & floodbasin \\
\hline $2 \mathrm{M} 22$ & floodbasin-levee transition zone \\
\hline 3 K25 & natural levee \\
\hline $3 \mathrm{~L} 15$ & ridges and swales in embanked floodplain \\
\hline $2 \mathrm{R} 11$ & abandoned channel \\
\hline $2 \mathrm{R} 12$ & crevasse channel \\
\hline
\end{tabular}

\section{Aeolian landforms}

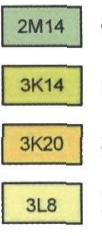

\section{Glacial and periglacial landforms}

\begin{tabular}{|c|c|}
\hline $2 M 7$ & plain of snow-meltwater deposits \\
\hline $4 \mathrm{H}^{2}$ & slope of snow-meltwater deposits \\
\hline $2 \mathrm{R} 3$ & dry valley \\
\hline $4 \mathrm{G} 3$ & alluvial fan \\
\hline $4 \mathrm{H} 7$ & slope of ice-pushed ridge \\
\hline $15 \mathrm{~B} 3$ & ice-pushed ridge (upper parts) \\
\hline
\end{tabular}

\section{Paludal landforms}

2M46 peaty plain (drained)

-... provincial boundary 
Fig. 3. Geomorphological map of the Westenholte study area (see Fig. 1 for location), with the location of the borehole cross-section Westenholte. This map is an updated detail from the Geomorphological Map of the Netherlands (Koomen \& Maas, 2004). The legend only explains the most important map units that are marked with codes. It shows the right margin of the IJssel channel belt, with a floodbasin extending to the northeast between (partly buried) aeolian riverdunes. The channel belt is bounded by a natural levee of irregular width. North of the aeolian riverdunes, crevasse splays exist in a peaty plain.

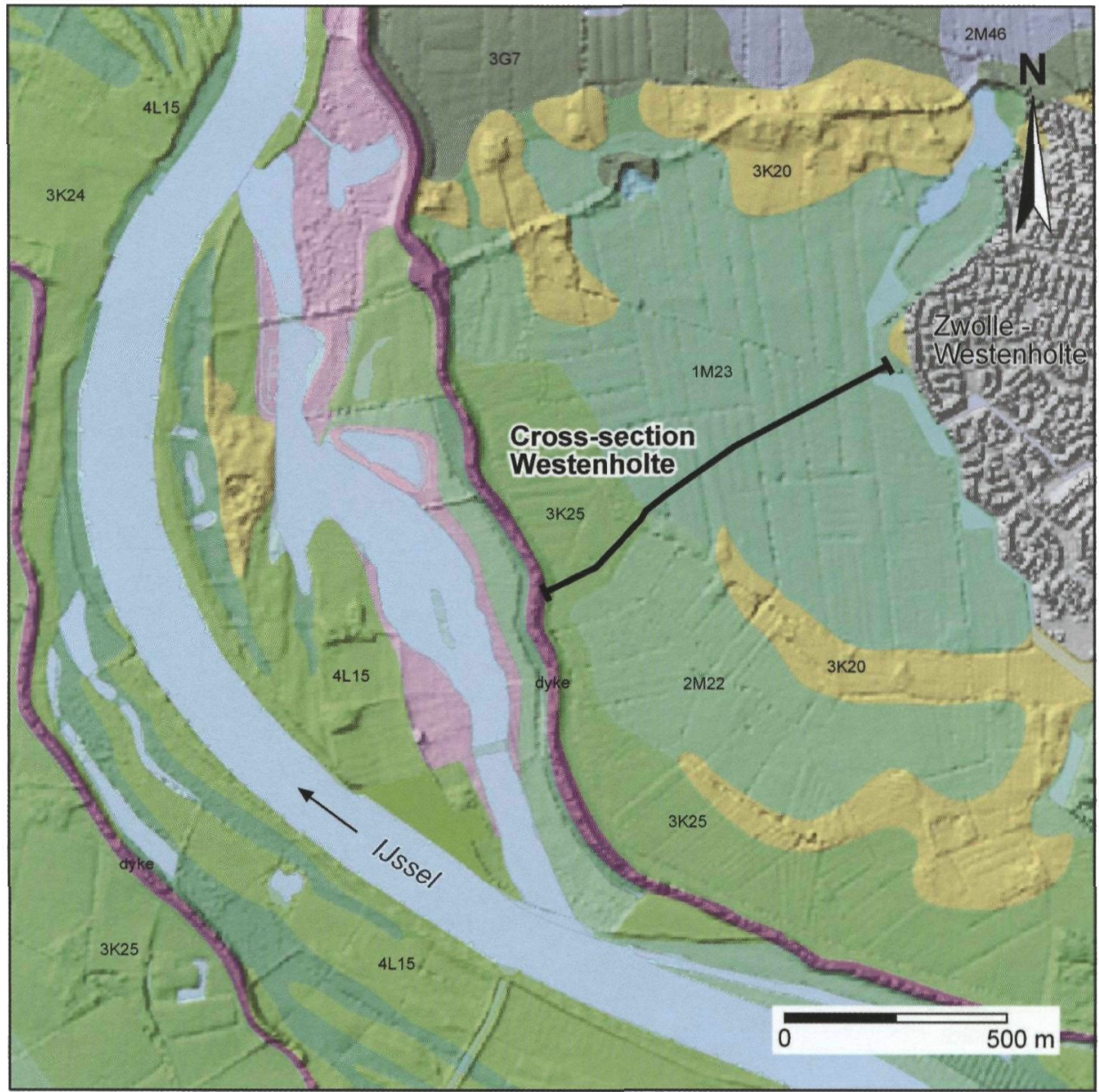

Fluvial landforms

1M23 floodbasin

2M22 floodbasin-levee transition zone

3 K25 natural levee

$3 K_{24}$ natural levee in embanked floodplain

4L15 ridges and swales in embanked floodplain

3G7 crevasse splay

\section{Aeolian landforms}

$3 \mathrm{~K} 20$ aeolian riverdune

\section{Paludal landforms}

$2 \mathrm{M} 46$

peaty plain (drained) the present IJssel channel (before normalisation), which was $\sim 150 \mathrm{~m}$. A remarkable aspect of the palaeochannel is that it hardly has associated natural levee deposits of silty and sandy clay, whereas these are well developed along the present IJssel channel. Whether the palaeochannel really preceded the present IJssel channel is unknown. The IJssel may also initially have been an anastomosing system in this reach. The fact that the present provincial boundary between Gelderland and 0verijssel, which dates back to medieval times, still partly follows this palaeochannel instead of the present IJssel channel, as it does elsewhere, underscores the former importance of the palaeochannel.

The peat bed in cross-section Wapenveld 1 thickens in a westward direction. Deposition of the thick natural levee near the present IJssel channel will undoubtedly have resulted in compaction of the underlying peat. However, erosion of peat will also have occurred, because the peat bed is totally lacking in the extreme eastern part of the cross-section. Likewise, near the palaeochannel erosion may have taken place. An undisturbed top of the peat bed, suitable for sampling, was expected in the extreme western part of the cross-section.

Cross-section Wapenveld 2 (Fig. 5), located $\sim 350 \mathrm{~m}$ downstream of cross-section Wapenveld 1 (Fig. 2), reveals a detailed picture of the lithostratigraphy of the distal IJssel overbank deposits and the underlying peat. This location is characterized by a gradual peat-clay transition. We sampled the very top of the peat (Fig. 5), directly below the transition to peaty clay (classification of organic sediments according to De Bakker \& Schelling, 1966). The botanical macroremains in the sampled peat were analysed using a binocular microscope and suitable 


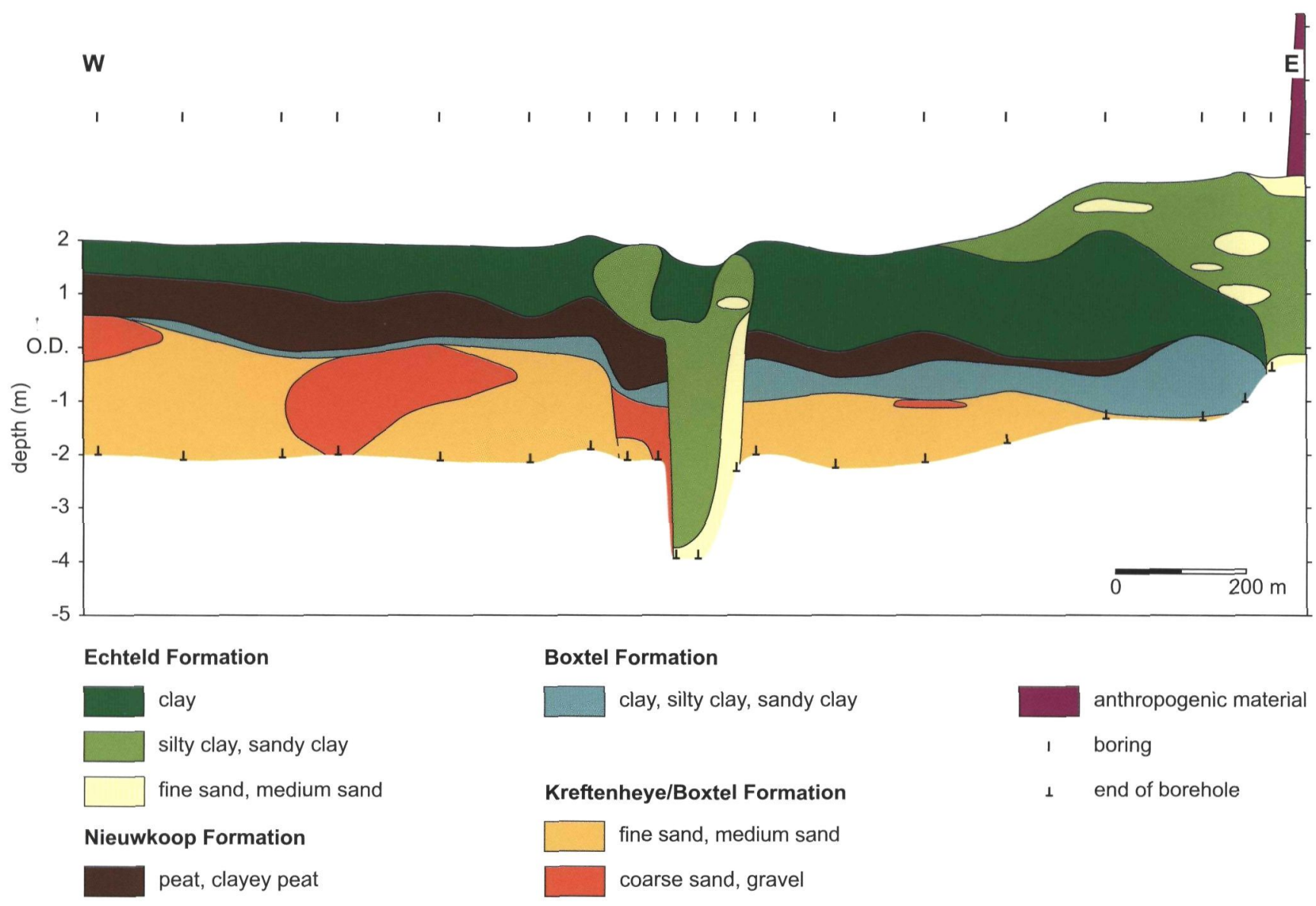

Fig. 4. Borehole cross-section Wapenveld 1 (see Fig. 2 for location). Borehole data were selected from the DINO database of TNO B\&O. The borings were carried out in 1994 by the Geological Survey of the Netherlands, now part of TNO B\&O. Sediment texture description is according to NEN 5104 (Nederlands Normalisatie-instituut, 1989) and the depth of bed boundaries was identified with a resolution of $10 \mathrm{~cm}$. Lithostratigraphical units (formations) according to Westerhoff et al. (2003).

remains were selected for radiocarbon age determination (for the selection procedure of macroremains, see Törnqvist et al., 1992). Our sample WAP-I consisted of seeds and fruits of Alisma plantago-aquatica, Carex, and Typha from a 1-cm-thick slice of a $3.5-\mathrm{cm}$-wide core. AMS age determination of this sample in the R.J. van de Graaff Laboratory (Utrecht University) yielded $1026 \pm 43{ }^{14} \mathrm{C}$ yr BP (Table 2). Calibration of this date (Table 3) gives 970 - $1046 \mathrm{AD}$ ( $1 \sigma$ range) as an age estimate for the beginning of IJssel overbank sedimentation at this location. w

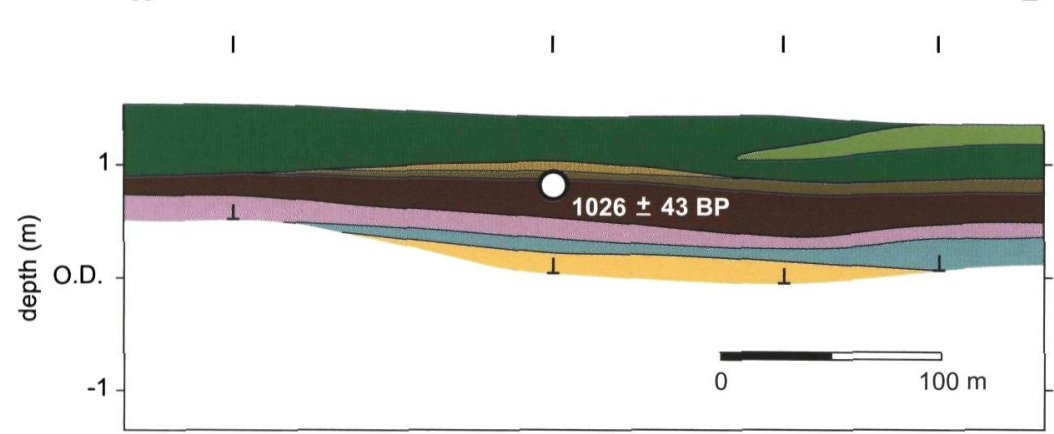

E

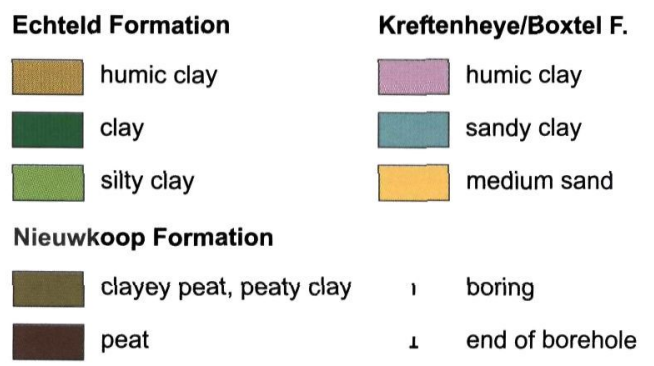

Fig. 5. Borehole cross-section Wapenveld 2 (see Fig. 2 for location) showing the position of radiocarbon-dated sample WAP-I (white dot). Note that horizontal and vertical scale is different from cross-section Wapenveld 1 (Fig. 4). Borings were carried out for this study using an Edelman auger and a gouge. Sediment properties were described every $10 \mathrm{~cm}$, following Berendsen \& Stouthamer (2001, pp. 29-32). The elevation of all borehole locations was measured relative to an absolute datum (NAP = Dutch Ordnance Datum). Lithostratigraphical units (formations) according to Westerhoff et al. (2003). 
Table 2. Radiocarbon age determinations from the lower IJssel floodplain carried out for this study.

\begin{tabular}{|c|c|c|c|c|c|c|}
\hline Sample & Laboratory number & $\begin{array}{l}{ }^{14} \mathrm{C} \text { age } \\
\left({ }^{14} \mathrm{C} \text { years } \mathrm{BP}\right)\end{array}$ & $\begin{array}{l}\text { Depth below surface } \\
\text { (cm) }\end{array}$ & $\begin{array}{l}\text { Co-ordinates and elevation of } \\
\text { core location relative to NAP }{ }^{1} \\
\text { (m) }\end{array}$ & $\begin{array}{l}\text { Mass C } \\
\text { (mg) }\end{array}$ & Material \\
\hline WAP-1 & UtC-14774 & $1026 \pm 43$ & $55-56$ & $203.397 / 492.597 /+1.43$ & 0.49 & fruits and seeds ${ }^{2}$ \\
\hline WH-I-1 & UtC-14771 & $1142 \pm 37$ & $60-62.5$ & $199.162 / 503.853 /+0.07$ & 2.08 & wood and bark \\
\hline WH-I-2 & UtC-14772 & $1143 \pm 55$ & $60-67.5$ & $199.162 / 503.853 /+0.07$ & 0.23 & fruits $^{3}$ \\
\hline $1 \mathrm{Co}-0$ & according to the D & co-ordinate syste & $\mathrm{AP}=$ Dutch 0rdnance $\mathrm{D}$ & & & \\
\hline 2 & lontano-aguntica fru & Carey fruits? & a seeds. & & & \\
\hline $34 \mathrm{Car}$ & iits 1 Denanthe aquat & ericarp, 2 Ranun & fruits, 1 Scirpus lact & it, 4 Urtica dioica fruits, 1 Apiaceae & it (meric & \\
\hline
\end{tabular}

Table 3. Calibration of radiocarbon ages.

\begin{tabular}{|c|c|c|c|c|c|}
\hline Sample & Laboratory number & $\begin{array}{l}{ }^{14} \mathrm{C} \text { age } \\
\left({ }^{14} \mathrm{C} \text { years } \mathrm{BP}\right)\end{array}$ & $\begin{array}{l}\text { Median cal. age }{ }^{1} \\
\text { (years AD) }\end{array}$ & $\begin{array}{l}1 \sigma \text { cal. age range }{ }^{1} \\
\text { (years } \mathrm{AD} \text { ) }\end{array}$ & $\begin{array}{l}2 \sigma \text { cal. age range }{ }^{1} \\
\text { (years } A D \text { ) }\end{array}$ \\
\hline WAP-1 & UtC-14774 & $1026 \pm 43$ & 1007 & $970-1046$ & $930-1098$ \\
\hline WH-I-1/WH-I-2 & UtC-14771/UtC-14772 & $1142 \pm 31^{2}$ & 896 & $866-938$ & $822-962$ \\
\hline Velperbroek & GrN-12602 & $1420 \pm 30$ & 621 & $594-654$ & $566-682$ \\
\hline V'broek Circuit & GrN-14407 & $1265 \pm 45$ & 770 & $726-814$ & $686-862$ \\
\hline $\begin{array}{r}1 \text { The Groningen } \\
\text { Bierkens (1994 } \\
\text { wood and terre }\end{array}$ & $\begin{array}{l}\text { ibration program (version CA } \\
\text { or the bulk samples Velperb } \\
\text { al macroremains, } \sigma_{\mathrm{s}}=60 \text { wa }\end{array}$ & $\begin{array}{l}\text { L25) was used (Van } \\
\text { roek and Velperbroe } \\
\text { s applied. }\end{array}$ & $\begin{array}{l}\sigma_{s}=200 \text { was applied } \\
\text {. The degree }\end{array}$ & $\begin{array}{l}\text { othing of the calibration } \\
\text { the samples WAP-1 and V }\end{array}$ & $\begin{array}{l}\text { was based on Törnqvist } 8 \\
\text { WH-I-2 that consisted of }\end{array}$ \\
\hline
\end{tabular}

\section{Westenholte study area}

Cross-section Westenholte (Fig. 6) shows surficial clayey overbank deposits on the right bank of the IJssel. In the southwestern part of the cross-section a 300-m-wide wedge of silty and sandy clay occurs, representing the natural levee of the IJssel. The dyke, that bounds the embanked part of the IJssel floodplain that extends to the west, rests on these natural levee deposits. Farther to the east, a clay bed extends into the floodbasin. The IJssel overbank deposits overlie a peat bed of variable thickness. The transition from peat (Nieuwkoop Formation) to clay (Echteld Formation) is generally gradual, through intervening layers of clayey peat, peaty clay and humic clay.

Most boreholes ended in a blue-grey, stiff, very sandy clay, with an admixture of relatively coarse material. The characteristics of this material are very different from the Holocene material and indicate a long period of non-deposition with weathering and soil formation. Only in one borehole, the sand that presumably underlies this bed of sandy clay everywhere in the cross-section was reached. The stiff clayey deposits seem to have a terraced upper surface, with a step of about $1 \mathrm{~m}$ in the south-western part of the cross-section, and could simply be interpreted as the top of the Kreftenheye Formation. A study in a pit nearby (Hamming et al., 1965), however, revealed a rather complicated picture of the stratigraphy between the Holocene peat and the top of the Kreftenheye deposits, with facies indicating much local reworking, and aeolian and local fluvial deposition. Such local deposits belong to the Boxtel Formation. With the present limited data, we leave open the possibility of a local origin of the basal deposits in Cross-section Westenholte.

A package of fine, poorly sorted sand rests on top of the stiff sandy clay in the central part of the cross-section. Sand body geometry and its location on the border of a terrace suggest an aeolian riverdune origin, and therefore it was classified as Boxtel Formation (Delwijnen Member) (Westerhoff et al., 2003). A thin bed of (humic) clay draping the lower level of the terraced surface in the south-western part of the cross-section is taken as a local river deposit analogous to the much thicker Boxtel Formation clay bed in the Wapenveld study area.

The top of the peat below the IJssel overbank deposits was sampled well outside the natural levee zone in order to minimize the risk of sampling below overbank deposits that erosively overlie the peat. At the sampling location there is a gradual transition from peat to clay, through peaty clay and humic clay. Like in cross-section Wapenveld 2, the very top of the peat, directly below the transition to peaty clay, was sampled (Fig.6). Analysis of botanical macroremains in the sample, yielded abundant wood and bark fragments, but only few seeds and fruits. We composed two subsamples for radiocarbon age determination: WH-I-1 consisting of wood and bark remains from a 2.5 -cm-thick core interval (diameter $3.5 \mathrm{~cm}$ ), 


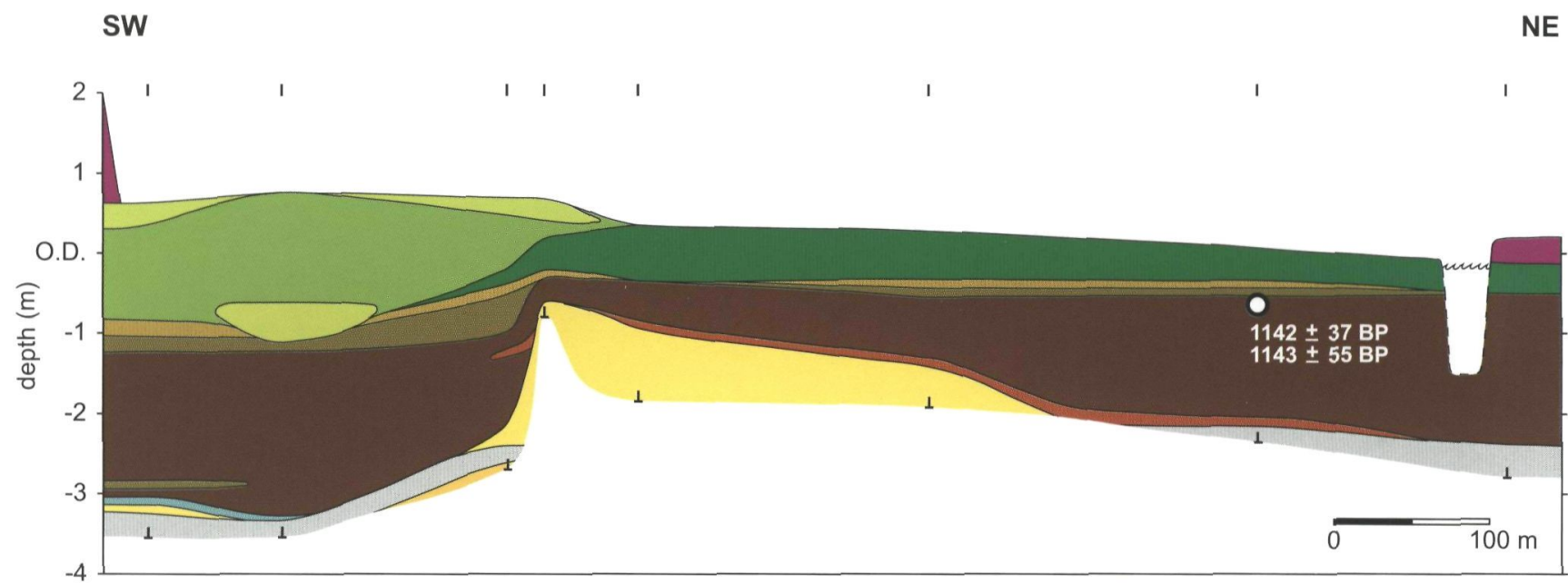

Echteld Formation

$\square$ humic clay
clay
$\square$ silty clay
$\square$ sandy clay

Boxtel Formation

humic clay, clay

fine sand, medium sand
Nieuwkoop Formation

clayey peat, peaty clay

peat

peaty sand, sandy peat

Krefenheye/ Boxtel Formation

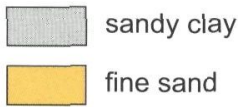

Fig. 6. Borehole cross-section from the Westenholte study area (see Fig. 3 for location) showing the position of radiocarbon-dated subsamples WH-I-1 and WH-I-2 (white dot). Borings were carried out for this study using an Edelman auger and a gouge. Sediment properties were described every $10 \mathrm{~cm}$, following Berendsen \& Stouthamer (2001, pp. 29-32). The elevation of all borehole locations was measured relative to an absolute datum (NAP = Dutch Ordnance Datum). Lithostratigraphical units (formations) according to Westerhoff et al. (2003).

and WH-I-2 consisting of seeds and fruits of various terrestrial plant species from a 7.5 -cm-thick core interval that includes and extends downward from the interval from which WH-I-1 was taken (Table 2). The scarcity of seeds and fruits necessitated combining remains from a relatively thick interval in order to reach a sufficiently large sample size. AMS age determination of the subsamples in the R.J. van de Graaff Laboratory yielded $1142 \pm 37{ }^{14} \mathrm{C}$ yr BP (WH-I-1) and $1143 \pm 55^{14} \mathrm{C}$ yr BP (WH-I-2) (Table 2). A weighted mean of these dates (1142 \pm 31 ${ }^{14} \mathrm{C}$ yr BP) was calibrated at 866-938 AD (1 $\sigma$ range) (Table 3 ), suggesting that overbank sedimentation at this location started about 100 years earlier than at the sampling site in the Wapenveld study area. The older age obtained in the Westenholte study area, may have been influenced by sampling from a relatively thick core interval (subsample WH-I-2), thereby including deeper, and thus older, material. 0n the other hand, the almost similar ages of the subsamples WH-I-1 and WH-I-2 suggest that this ageing effect is very small.

Only $2.6 \mathrm{~km}$ north-northeast of our Westenholte sampling site, the top of a bed of (clayey) peat overlain by clay was radiocarbon-dated at $1540 \pm 30{ }^{14} \mathrm{C}$ yr $\mathrm{BP}$ (474-538 $\mathrm{AD} ; 1 \sigma$ range) by Kooistra et al. (2006). Dendrochronological dating of associated oak and ash tree remains (Sass-Klaassen \& Hanraets,
2006) confirmed this AMS bulk peat radiocarbon date. We agree with Kooistra et al. (2006) that the clay bed directly above the dated peat at this location belongs to the River Vecht and not to the IJssel. The floodplain site investigated by Kooistra et al. (2006) is separated from the IJssel floodplain west of Westenholte by aeolian riverdunes and a coversand ridge. Clay texture as described by Kooistra et al. (2006) (almost $100 \%<2 \mu \mathrm{m}$ ) differs strongly from grain size characteristics of IJssel overbank deposits (e.g. Stiboka, 1966, p. 114-115).

\section{Interpretation of the new radiocarbon data}

For methodological reasons, the new radiocarbon dates presented above are superior to previous radiocarbon dates indicating the beginning of IJssel overbank sedimentation. The new dates are AMS dates of selected botanical macroremains, which are generally more accurate than conventional dates of bulk peat samples (Törnqvist et al., 1992), such as the previous dates from the upper IJssel floodplain. Also, the new dates can be expected to relate closer to beginning IJssel overbank sedimentation, because only pure, intact peat directly beneath gradual peat-clay transitions was sampled. All previous samples were taken from less optimal contexts, i.e., from decomposed 
or clayey peat beds, from below sharp peat-clay boundaries or from too far below the very top of the peat. Probably because of methodological improvements and a more precise sampling procedure our radiocarbon dataset is much more consistent than the dataset available hitherto.

We also consider the lower IJssel floodplain to be a more suitable sampling area than the upper IJssel floodplain. Van de Meene (1977, p. 63) described Rhine floodwaters to have passed through the Oude IJssel valley (Fig. 1) since Subboreal times. These have inundated and deposited clay on the upper IJssel floodplain. Therefore, at locations 1 and 2 (Fig. 1) only clayey peats exist (Teunissen, 1990). Moreover, in the whole Rhine-Meuse delta clastic sedimentation increased after 2000 BP and peat formation came to an end (Pons, 1957; De Boer \& Pons, 1960; Berendsen, 1990; Berendsen \& Stouthamer, 2001, p. 89). In this context, the fact that a number of radiocarbon dates indicate end of peat formation on the upper IJssel floodplain in the Roman Period (12 BC - 425 AD; Willems, 1986) is not surprising, and may not have been caused by the formation of the IJssel channel, but rather by a regional change in sedimentation style of the Rhine system that probably already started 3000 cal yr BP (Gouw \& Erkens, 2007). Therefore, radiocarbon dates from the lower IJssel floodplain, located well outside the zone of clastic overbank deposition of Rhine branches other than the IJssel, are more indicative of the time of IJssel channel formation.

Calibrated ages from the Wapenveld and Westenholte study areas differ about 100 years (Table 3). Taking into account the resolution associated with the methodology of ${ }^{14} \mathrm{C}$ dating Holocene channel belts (estimated to be about \pm 100 years by Berendsen \& Stouthamer (2000, p. 320)), this means that the dates from both areas are essentially similar. Considering the overlap of the $2 \sigma$ ranges of the calibrated ages (Table 3 ), onset of overbank sedimentation in the lower IJssel area can be estimated to have started $\sim 950 \mathrm{AD}$. To which extent is this important environmental change on the lower IJssel floodplain a response to channel formation upstream in the reach Westervoort-Doesburg?

Some authors argued that the upper IJssel could have existed for a very long period ( 1000 year), without widespread deposition of overbank sediments (Harbers \& Mulder, 1981). This notion is in conflict with the concepts underlying the extensive palaeogeographical work carried out by Berendsen (1982), Berendsen \& Stouthamer $(2000,2001)$ and many coworkers, leading to excellent reproducible results over the last three decades. Moreover, this notion is contradicted by research in modern fluvial environments, showing that the formation of a new channel by avulsion is accompanied by widespread sedimentation stopping peat growth (Smith et al., 1989). Therefore, we exclude the possibility that the upper IJssel existed very long before the 10th century $A D$, and rather consider the onset of lower IJssel overbank sedimentation as a response to the establishment of a connnection between the local IJssel valley drainage system and the Rhine. This connection transformed the local river with a small catchment delivering little sediment into a much larger river with a vast hinterland delivering large amounts of sediment.

A point of discussion remains whether there has been a limited time lag between formation of the upper IJssel channel, and sedimentation on the lower IJssel floodplain near Wapenveld and Westenholte. The available radiocarbon data suggest so. As argued above, the older part of the upper IJssel floodplain radiocarbon data set (GrN-5491 (2000 $\pm 65{ }^{14} \mathrm{C}$ yr BP), GrN-7525 (1720 $\pm 25{ }^{14} \mathrm{C}$ yr BP) and GrN-10293 (1575 $\pm 35^{14} \mathrm{C}$ yr BP) (Table 1)) has low indicative value for the start of IJssel channel formation, and is probably subject to errors related to sampling material and sampling site conditions. However, the younger part of the data set ( GrN-12602 (1420 \pm $30{ }^{14} \mathrm{C}$ yr BP) and $\mathrm{GrN}-14407\left(1265 \pm 45{ }^{14} \mathrm{C}\right.$ yr BP) (Table 1)) needs serious consideration. The latter date is certainly somewhat too young to indicate initiation of IJssel channel formation because it represents clayey peat on top of peat; i.e., IJssel clay deposition had already started when the dated material formed. The former date represents a sample collected $\sim 500 \mathrm{~m}$ farther from the IJssel channel belt, at a location where thin peat grades upward into humic clay. Field inspection of the sampling site for the present research yielded an apparently non-erosive peat-clay transition. With the sample having been taken almost directly below the humic clay bed (unpubl. description D. Teunissen), GrN-12602 (1420 $\pm 30{ }^{14} \mathrm{C}$ yr BP) can be interpreted to indicate beginning of upper IJssel overbank sedimentation at about $600 \mathrm{AD}$ (Table 3) (note that the above-mentioned methodological resolution, about \pm 100 years (Berendsen \& Stouthamer, 2000, p. 320), also applies to this estimate). This would imply a time lag of $\sim 350$ years between onset of upper and lower IJssel floodplain sedimentation. Interesting in this context is that IJssel-delta progradation was interpreted by Ente (1973 - 1974) to have started in the 12 th century AD, i.e., another $\sim 200$ years later.

If, in spite of some remaining uncertainties, the younger part of the upper IJssel radiocarbon dataset ( GrN-12602 and GrN-14407) is accepted, one could propose a model of IJssel channel-belt progradation, as a part of a relatively slow avulsion process (cf. Smith et al., 1989; Farrell, 2001), accounting for a downstream decreasing age of first IJssel sedimentation.

\section{The IJssel avulsion}

In the course of the Holocene, many avulsions have occurred in the Rhine-Meuse delta (e.g. Stouthamer \& Berendsen, 2000; Makaske et al., 2007) as a result of aggradation of channel belts above the surrounding floodplain (Berendsen \& Stouthamer, 2001). The steep cross-levee slopes developing near the channel usually play an important role in the early stages of the avulsion process (Slingerland \& Smith, 1998), when a crevasse in the levee develops and routes water and 
sediments to the floodplain. Farther away, on the floodplain, gradients approach the general valley slope. An energetically favourable avulsion route on the floodplain must exist for an avulsion to be completed, i.e., to result in the formation of new channel belt (cf. Makaske, 2001, p. 158).

In the case of the IJssel avulsion, the first reach of the avulsion route must have had a relatively low gradient, which may have been a reason for initial slow avulsion-belt progradation. Nowadays, there is hardly any difference between channel-belt gradients for various reaches of the IJssel (Fig. 7). Originally, however, a low divide existed near Doesburg consisting of the top of the Middle-Weichselian Rhine terrace that was formed before abandonment of the IJssel valley by the Rhine. A digital elevation model of the Doesburg area (Fig. 8) shows intact parts of this divide at the present surface. From this divide, the Middle-Weichselian terrace dips to the north largely being exposed at the surface in juxtaposition to (and slightly above) the modern IJssel channel belt. North of Deventer, the terrace is covered with Holocene IJssel deposits and it presumably corresponds to the upper terrace levels identified in the subsurface in the Wapenveld and Westenholte study areas (Figs 4 and 6). From the divide near Doesburg the terrace also dips to the southwest, as indicated by the top level of terrace remnants. In this area, however, southwest dipping Late-Weichselian terraces constitute most of the Pleistocene subsurface below the Holocene peat and alluvium. LateHolocene aggradation in this area had to compensate for the reverse slope in the Pleistocene surface to enable water to spill over the divide near Doesburg into the steeper middle IJssel valley. An important question is to which extent this divide was still intact when the IJssel avulsion was taking place.

In Figure 8 a few crevasse channels crossing the divide can be identified east of Doesburg. They dissect aeolian dunes lining the northern boundary of the Late-Weichselian terrace that underlies the Oude IJssel valley. Because the aeolian dunes are essentially Late-Weichselian features (Van de Meene, 1977, pp. 44-45) the crevasse channels are younger, probably Holocene in age. A Holocene age is suggested by poorly developed soils and clay admixture in the associated sandy crevasse splays (Stiboka, 1975). The crevasse splays are non-calcareous (Stiboka, 1975) indicating that they predominantly consist of locally eroded Pleistocene material. This suggests that the crevasse splays formed before the IJssel avulsion introduced large amounts of fresh calcareous sediments (i.e., the material found in the IJssel channel belt today) into the area. We feel that the Oude IJssel played a role in crevasse splay formation.

The present Oude IJssel is a small local river that seems incapable to form crevasses of the size observed on its own. We hypothesize that Rhine floodwaters initiated crevasse splay formation. When the Rhine started to spill into the Oude IJssel valley in the Subboreal (Van de Meene, 1977; Fig. 1), infilling of the Oude IJssel valley with Holocene sediments gradually reduced the relief along the divide and forced extreme Rhine floods to seek an outlet across the divide eroding gaps into it. One of these crevasses near Doesburg, in the lowest part of the divide, may have caused a northward avulsion of the Oude IJssel. Possibly, a small pre-existing stream draining seepage water from the ice-pushed ridge that borders the IJssel valley to the west, guided the Oude IJssel avulsion route northward down the Middle-Weichselian terrace, linking it to the lower IJssel valley drainage system. Before that time, the Oude IJssel more likely flowed southwestward into the RhineMeuse delta joining the Rhine near Arnhem, thereby following the overall gradient of the shallow Late-Weichselian subsurface. Increasing aggradation in the Arnhem area during the late Holocene must have hampered drainage of the Oude IJssel in
Fig. 7. Gradient lines of the IJssel channel belt and the Middle-Weichselian terrace. Data points for the IJssel channel belt represent highest surface levels of early IJssel point bars as identified on a digital elevation model (AHN). Data points for the MiddleWeichselian terrace represent AHN surface levels near the IJssel channel belt, and data from Pons (1953) and Figs 4, 5 and 6 where the terrace is in the subsurface. Gradient lines were fitted by the eye.

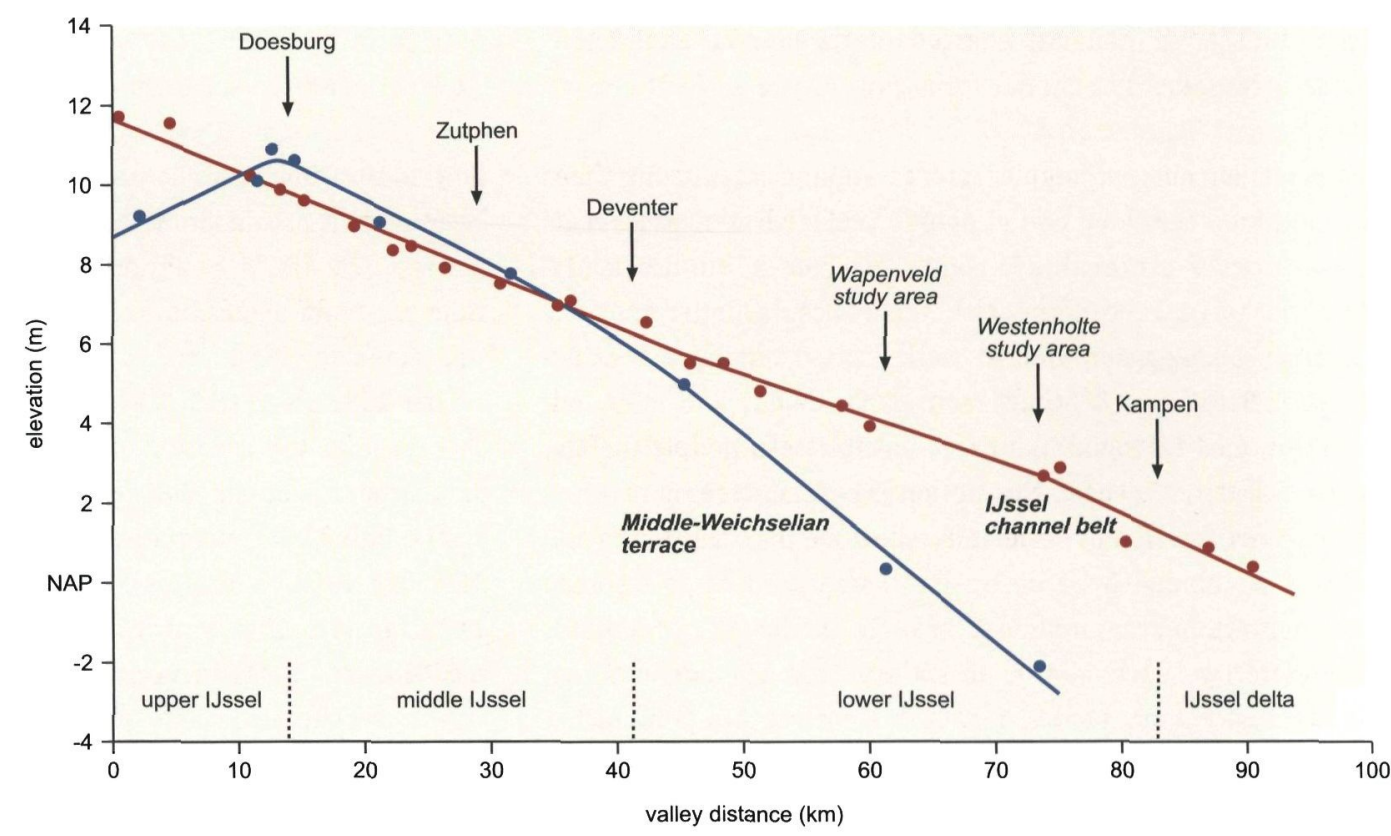




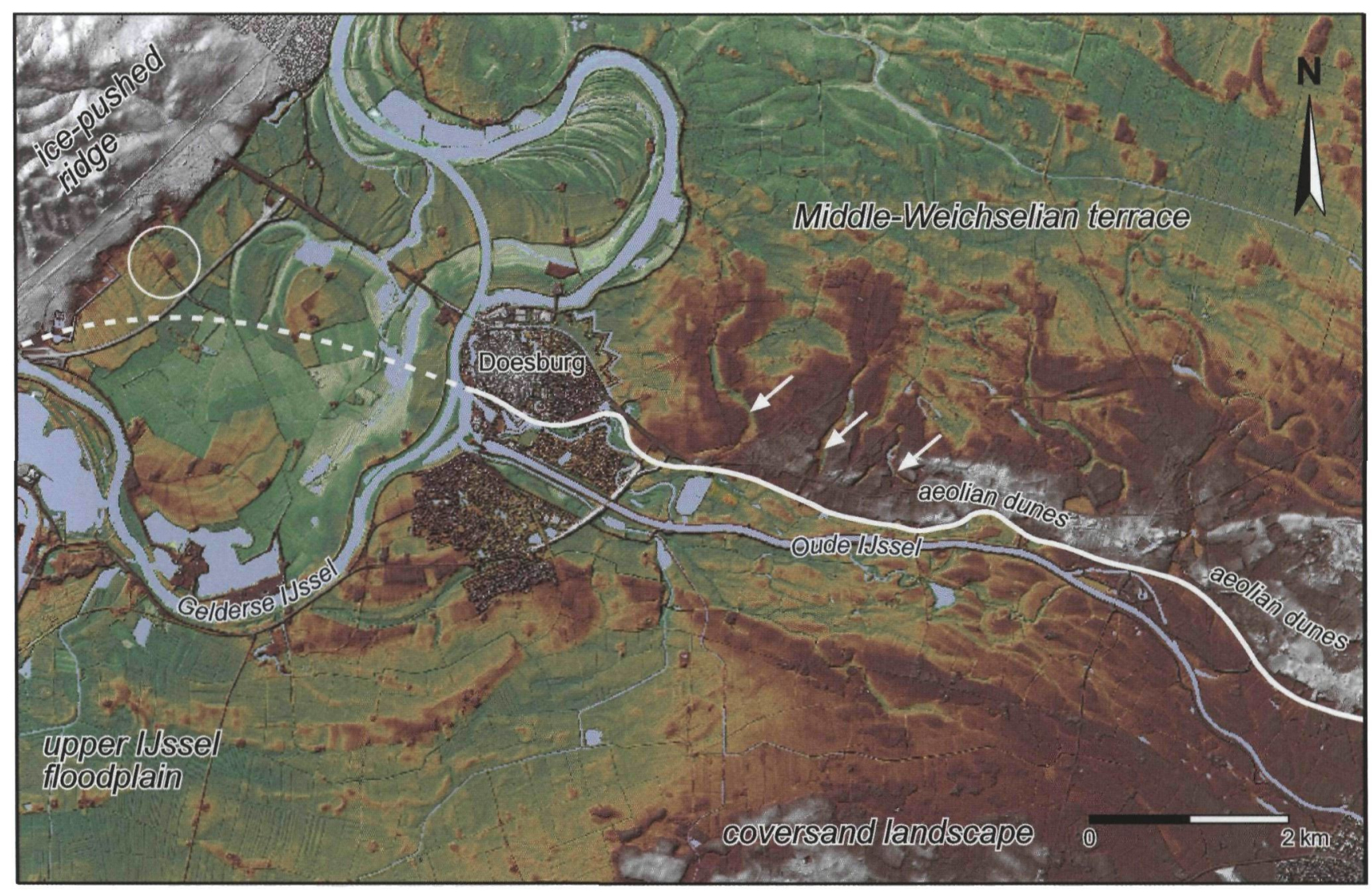

Fig. 8. Digital elevation model (AHN $5 \times 5 \mathrm{~m}$; Van Heerd et al., 2000) of the area around Doesburg (see Fig. 1 for location), showing the former divide between the IJssel valley catchment to the north and the Rhine catchment to the south. Colours in order of increasing elevation: green-yellow-red-white. The former divide approximately follows the southern edge of the Middle-Weichselian terrace (white line). Directly west of Doesburg the IJssel broke through the divide (presumed former edge of the Middle-Weichselian terrace indicated by dashed white line) and eroded the terrace. A high (fieldchecked) terrace remnant remains west of the IJssel (white circle). East of Doesburg crevasse channels in the edge of the Middle-Weichselian terrace can be seen (white arrows).

this direction, contributing to a northward avulsion. Continuing Rhine channel belt aggradation, ultimately reversed the surface gradient between Westervoort and Doesburg and led to the IJssel avulsion that perhaps reactivated (parts of) the abandoned lower Oude IJssel course.

Anyway, the geomorphological data suggest that the IJssel avulsion has been a complex process taking significant time, which would explain how upper IJssel sedimentation may have started earlier than lower IJssel sedimentation. It can also be expected that incision of the middle IJssel channel into the generally stiff, consolidated Middle-Weichselian terrace has been a slow process, initially limiting the amounts of sediment that could be transported to the lower IJssel floodplain. This concept fits with the typically very gradual transition from peat to floodplain clay observed in the lower IJssel floodplain [Hamming et al. (1965) even distinguished finer old IJssel clay and sandier younger IJssel clay] and also would explain the apparent time lag between initial channel formation and IJssel-delta progradation (Ente, 1973-1974). The gradual transition from peat to floodplain clay speaks against the hypothesis that the IJssel avulsion was a catastrophic event, triggered by a single extreme Rhine flood, as proposed by Cohen \& Lodder (2007), based on preliminary observations on crevasses and splays in the IJssel valley.

\section{Conclusions}

New AMS radiocarbon age determinations indicate that overbank sedimentation along the lower reach of the Gelderse IJssel started $950 \mathrm{AD}$. This environmental change most likely resulted from an avulsion of the Rhine into the IJssel valley. Prior to this avulsion, only local streams carrying minor amounts of sediment existed in the IJssel valley during most of the Holocene. Reinterpretation of previous conventional radiocarbon data from the upper IJssel floodplain leads to the conclusion that upper IJssel channel formation may have started $~ 600$ AD. Our results contradict earlier suppositions, based on interpretation of archaeological data and historical accounts, that the Gelderse IJssel is much older and originated as a canal, dug under supervision of the Roman general Drusus.

Geomorphological and soil data suggest that the IJssel avulsion was a slow process, retarded by a low gradient of the 
first reach of the avulsion route, and an erosion-resistant subsurface (the strongly consolidated top of the MiddleWeichselian terrace) in the middle reach of the avulsion route. These particular conditions caused the IJssel avulsion to have been different in process and rate from many other Holocene avulsions in the Rhine-Meuse delta, which might explain the apparent time lag between the beginning of upper and lower IJssel overbank sedimentation.

The early-medieval age of the Gelderse IJssel suggests that the IJssel avulsion has been an important trigger for the rise of medieval trading cities on the IJssel like Zutphen, Deventer, Kampen and Doesburg.

\section{Acknowledgements}

We wish to thank Arjan Koomen for managing the project GKN (Geomorphological Map of the Netherlands), in the framework of which the present work was carried out. Klaas van der Borg (R.J. van de Graaff Laboratory, Utrecht University) is thanked for carrying out high-quality radiocarbon age determinations. TNO-B\&0 kindly supplied borehole data for Fig. 4. Frans Bunnik, Joop Kalis and Hans van der Plicht were very helpful in the search for details about radiocarbon dates used by the late Dr D. Teunissen. We appreciated the thoughtful comments of the journal reviewers Kim Cohen and Henk Weerts.

\section{References}

Berendsen, H.J.A., 1982. De genese van het landschap in het zuiden van de provincie Utrecht, een fysisch-geografische studie. Utrechtse Geografische Studies 25: $259 \mathrm{pp}$.

Berendsen, H.J.A., 1990. River courses in the Central Netherlands during the Roman Period. Berichten van de Rijksdienst voor het Oudheidkundig Bodemonderzoek 40: 243-249.

Berendsen, H.J.A. \& Stouthamer, E., 2000. Late Weichselian and Holocene palaeogeography of the Rhine-Meuse delta, the Netherlands. Palaeogeography, Palaeoclimatology, Palaeoecology 161: 311-335.

Berendsen, H.J.A. \& Stouthamer, E., 2001. Palaeogeographic development of the Rhine-Meuse delta, The Netherlands. Van Gorcum (Assen): 268 pp.

Berendsen, H.J.A., Hoek, W.Z. \& Schorn, E.A., 1995. Late Weichselian and Holocene river channel changes of the rivers Rhine and Meuse in the Netherlands (Land van Maas en Waal). Paläoklimaforschung/Palaeoclimate Research 14: 151-171.

Bos, J.A.A., Van Geel, B., Groenewoudt, B.J. \& Lauwerier, R.C.G.M., 2005. Early Holocene environmental change, the presence and disappearance of early Mesolithic habitation near Zutphen (the Netherlands). Vegetation History and Archaeobotany 15: 27-43.

Busschers, F.S., Kasse, C., Van Balen, R.T., Vandenberghe, J., Cohen, K.M., Weerts, H.J.T., Wallinga, J., Johns, C., Cleveringa, P. \& Bunnik, F.P.M., 2007. Late Pleistocene evolution of the Rhine-Meuse system in the southern North Sea basin: imprints of climate change, sea level oscillation and glacioisostacy. Quaternary Science Reviews 26, pp. 3216-3248.
Cohen, K.M., 2003. Differential subsidence within a coastal prism; Late-Glacial - Holocene tectonics in the Rhine-Meuse delta, the Netherlands. Nederlandse Geografische Studies 316: $172 \mathrm{pp}$.

Cohen, K.M. \& Lodder, Q.J., 2007. Paleogeografie en veiligheid tegen overstromen; de bruikbaarheid van inzichten in de ontwikkeling van de Nederlandse delta in de laatste 5000 jaar voor het kwantitatief begrenzen van overstromingsmagnitudes en -frequenties. RWS RIZA rapport 2007.016, Rijkswaterstaat RIZA (Lelystad): 80 pp.

De Bakker, H. \& Schelling, J., 1966. Systeem van bodemclassificatie voor Nederland; de hogere niveaus. Pudoc (Wageningen), 217 pp.

De Boer, Th.A. \& Pons, L.J., 1960. Bodem en grasland in de Vijtheerenlanden. Verslagen van landbouwkundige onderzoekingen 66.6, Pudoc (Wageningen): $72 \mathrm{pp}$.

Ente, P.J., 1971. Sedimentary geology of the Holocene in Lake IJssel region. Geologie en Mijnbouw 50: 373-382.

Ente, P.J., 1973-1974. De IJsseldelta. Kamper Almanak (Kampen): 137-164.

Eilander, D.A. \& Heijink, W., 1990. Bodemkaart van Nederland, schaal 1 : 50.000; toelichting bij de kaartbladen 20 West Lelystad (gedeeltelijk), 20 0ost Lelystad en 21 West Zwolle. Staring Centrum (Wageningen): 165 pp.

Farrell, K.M., 2001. Geomorphology, facies architecture, and high-resolution, non-marine sequence stratigraphy in avulsion deposits, Cumberland Marshes, Saskatchewan. Sedimentary Geology 139: 93-150.

Gouw, M.J.P. \& Erkens, G., 2007. Architecture of the Holocene Rhine-Meuse delta (the Netherlands); a result of changing external controls. Netherlands Journal of Geosciences - Geologie en Mijnbouw 86: 23-54.

Hamming, C., Knibbe, M. \& Maarleveld, G.C., 1965. Afzettingen van de IJssel, nabij Zwolle. Boor en Spade 14: 88-103.

Harbers, P. \& Mulder, J.R., 1981. Een poging tot reconstructie van het Rijnstelsel in het oostelijk rivierengebied tijdens het Holoceen, in het bijzonder de Romeinse tijd. K.N.A.G. Geografisch Tijdschrift 15: 404-421.

Kooistra, M.J., Kooistra, L.I., Van Rijn, P. \& Sass-Klaassen, U., 2006. Woodlands of the past; the excavation of wetland woods at Zwolle-Stadshagen (the Netherlands): reconstruction of the wetland wood in its environmental context. Netherlands Journal of Geosciences - Geologie en Mijnbouw 85: $37-60$.

Koomen, A.J.M. \& Maas, G.J., 2004. Geomorfologische Kaart Nederland (GKN); achtergronddocument bij het landsdekkende digitale bestand. Alterrarapport 1039, Alterra (Wageningen): 38 pp.

Lanting, J.N. \& Mook, W.G., 1977. The pre- and protohistory of the Netherlands in terms of radiocarbon dates. (Groningen): $247 \mathrm{pp}$.

Makaske, B., 2001. Anastomosing rivers: a review of their classification, origin and sedimentary products. Earth-Science Reviews 53: 149-196.

Makaske, B., Berendsen, H.J.A. \& Van Ree, M.H.M., 2007. Middle Holocene avulsion-belt deposits in the central Rhine-Meuse delta, the Netherlands. Journal of Sedimentary Research 77: 110-123.

Nederlands Normalisatie-instituut, 1989. NEN 5104: Geotechniek; classificatie van onverharde grondmonsters. Nederlands Normalisatie-instituut (Delft): $23 \mathrm{pp}$.

Poelman, J.N.B., 1981a. De gracht van Drusus? Westerheem 30: 20-23.

Poelman, J.N.B., 1981b. Facta non fabula. Westerheem 30: 173-176.

Poelman, J.N.B. \& Harbers, P., 1966. Heeft Lathum altijd aan de rechter IJsseloever gelegen? Boor en Spade 15: 128-130. 
Pons, L.J., 1953. De bodemgesteldheid van een gedeelte van de Lijmers (het binnendijkse land van de gem. Westervoort, Duiven (ged.) en Zevenaar (ged.)). Rapport 343, Stichting voor Bodemkartering (Wageningen): $58 \mathrm{pp}$.

Pons, L.J., 1957. De geologie, de bodemvorming en waterstaatkundige ontwikkeling van het Land van Maas en Waal en een gedeelte van het Rijk van Nijmegen. Mededelingen van de Stichting voor Bodemkartering, Bodemkundige Studies 3, Stichting voor Bodemkartering (Wageningen): $156 \mathrm{pp}$.

Sass-Klaassen, U. \& Hanraets, E., 2006. Woodlands of the past; the excavation of wetland woods at Zwolle-Stadshagen (the Netherlands): growth pattern and population dynamics of oak and ash. Netherlands Journal of Geosciences - Geologie en Mijnbouw 85: 61-71.

Slingerland, R. \& Smith, N.D., 1998. Necessary conditions for a meanderingriver avulsion. Geology 26: 435-438.

Smith, N.D., Cross, T.A., Dufficy, J.P., \& Clough, S.R., 1989. Anatomy of an avulsion. Sedimentology 36: 1-23.

Stiboka, 1966. Bodemkaart van Nederland, schaal 1:50.000; toelichting bij kaartblad 27 0ost Hattem. Stichting voor Bodemkartering (Wageningen): $126 \mathrm{pp}$.

Stiboka, 1975. Bodemkaart van Nederland, schaal 1: 50.000; toelichting bij de kaartbladen 40 West Arnhem en 40 0ost Arnhem. Stichting voor Bodemkartering (Wageningen): $197 \mathrm{pp}$.

Stouthamer, E. \& Berendsen, H.J.A., 2000. Factors controlling the Holocene avulsion history of the Rhine-Meuse delta (the Netherlands). Journal of Sedimentary Research 70: 1051-1064.

Teunissen, D., 1975. De wordingsgeschiedenis van het natuurlijke landschap van de Duffelt. Numaga 22: 79-94.

Teunissen, D., 1980. Enkele gebeurtenissen uit het leven van de Romeinse veldheer Drusus in het licht van enige nieuwe geologische gegevens uit oostelijk Gelderland. Westerheem 29: 321-334.

Teunissen, D., 1981. Nogmaals Drusus. Westerheem 30: 167-168 pp.

Teunissen, D., 1988. De bewoningsgeschiedenis van Nijmegen en omgeving, haar relatie tot de landschapsbouw en haar weerspiegeling in palynologische gegevens. Mededelingen van de Afdeling Biogeologie van de Sectie Biologie van de Katholieke Universiteit van Nijmegen 15: 108 pp.

Teunissen, D., 1990. Palynologisch onderzoek in het oostelijk rivierengebied: een overzicht. Mededelingen van de Afdeling Biogeologie van de Sectie Biologie van de Katholieke Universiteit van Nijmegen 16: 161 pp.

Törnqvist, T.E., 1993. Fluvial sedimentary geology and chronology of the Holocene Rhine-Meuse delta, the Netherlands. Nederlandse Geografische Studies 166: $169 \mathrm{pp}$.

Törnqvist, T.E. \& Bierkens, M.P.F., 1994. How smooth should curves be for calibration of radiocarbon ages? Radiocarbon 36: 11-26.

Törnqvist, T.E., De Jong, A.F.M., Oosterbaan, W.A. \& Van der Borg, K., 1992. Accurate dating of organic deposits by AMS ${ }^{14} \mathrm{C}$ measurement of macrofossils. Radiocarbon 34: 566-577.

Van de Meene, E.A., 1977. Toelichtingen bij de geologische kaart van Nederland schaal 1 : 50.000; blad Arnhem 0ost (400). Rijks Geologische Dienst (Haarlem): $147 \mathrm{pp}$.

Van de Meene, E.A., 1979. Het ontstaan van de Geldersche IJssel. K.N.A.G. Geografisch Tijdschrift 13: 202-210.

Van der Plicht, J., 1993. The Groningen radiocarbon calibration program. Radiocarbon 35: 231-237.
Van Heerd, R.M., Kuijlaars, E.A.C., Teeuw, M.P. \& Van 't Zand, R.J., 2000. Productspecificatie AHN 2000. Rapport MDTGM 2000.13, Rijkswaterstaat, Adviesdienst Geo-informatie en ICT (Delft): 22 pp.

Verbraeck, A., 1990. De Rijn aan het einde van de laatste ijstijd: de vorming van de jongste afzettingen van de Formatie van Kreftenheye. K.N.A.G. Geografisch Tijdschrift 23: 328-339.

Vogel, J.C. \& Waterbolk, H.T., 1972. Groningen radiocarbon dates X. Radiocarbon 14: 6-110.

Westerhoff, W.E., Wong, T.E. \& De Mulder, E.F.J., 2003. Opbouw van de ondergrond. In: De Mulder, E.F.J., Geluk, M.C., Ritsema, I.L., Westerhoff, W.E. \& Wong, Th.E. (eds): De ondergrond van Nederland. Wolters-Noordhoff (Groningen/Houten): 247-352.

Willems, W.J.H., 1980. Arnhem - Meinerswijk: een nieuw castellum aan de Rijn. Westerheem 29: 334-348.

Willems, W.J.H., 1981. Over een fossa, een castra en een tabula. Westerheem 30: $168-171$.

Willems, W.J.H., 1986. Romans and Batavians; a regional study in the Dutch eastern river area. $\mathrm{PhD}$ thesis, University of Amsterdam (Amsterdam): $491 \mathrm{pp}$. 